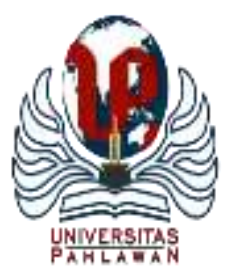

Edukatif : Jurnal Ilmu Pendidikan Volume 4 Nomor 1 Tahun 2022 Halm 582 - 589

EDUKATIF: JURNAL ILMU PENDIDIKAN

Research \& Learning in Education

https://edukatif.org/index.php/edukatif/index

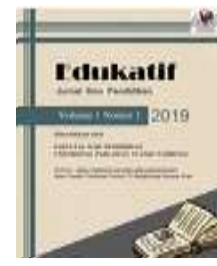

\title{
Analisis Konten Modul Pelajaran Mikrokontroller Terhadap Keterampilan Berpikir Kritis dan Kreativitas Siswa Sekolah Menengah Kejuruan
}

\section{Teguh Wijaksana Isma ${ }^{1 凶}$, Elfi Tasrif ${ }^{2}$, Yasdinul Huda ${ }^{3}$, Nurhasan $\mathrm{Syah}^{4}$}

Pendidikan Teknologi dan Kejuruan, Universitas Negeri Padang, Indonesia ${ }^{1,2,3,4}$

E-mail : teguhwijaksana@gmail.com ${ }^{1}$, elfitasrif@ft.unp.ac.id ${ }^{2}$, yasdinul5330@ft.unp.ac.id ${ }^{3}$, nurhasan_s@yahoo.com ${ }^{4}$

\begin{abstract}
Abstrak
Salah satu permasalahan pada pendidikan vokasional adalah tingginya angka pengangguran pada lulusan vokasional. Hal tersebut disebabkan karena guru dalam mengembangkan modul lebih berfokus kepada hardskill dibanding softskill seperti keterampilan berpikir kritis dan keterampilan kreatifitas. Penelitian ini bertujuan untuk menganalisis tentang konten modul pelajaran mikrokontroller terhadap keterampilan berpikir kritis dan kreativitas siswa Sekolah Menengah Kejuruan. Penelitian dilakukan di Sekolah Menengah Kejuruan Negeri 1 Sumatera Barat. Penelitian menggunakan metode deskriptif analisis. Penelitian yang dilakukan berfokus kepada pengaruh konten modul terhadap keterampilan berpikir kritis dan kreativitas siswa SMK. Teknik pengumpulan data yang digunakan dalam penelitian adalah angket. Subjek penelitian adalah guru yang mengajar mata pelajaran mikrokontroller. Teknik analisis data yang digunakan dalam penelitian adalah mixed method. Hasil penelitian menunjukkan bahwa keterampilan berpikir kritis dan Kreativitas siswa SMK N 1 Sumatera Barat berada pada kategori sangat baik. Selain itu konten modul pelajaran yang digunakan meningkatkan keterampilan berpikir kritis dan kreativitas siswa SMK N 1 Sumatera Barat.
\end{abstract}

Kata Kunci: Sekolah Menengah Kejuruan, Konten, Modul, Berpikir Kritis, Kreativitas

\begin{abstract}
One of the problems in vocational education is the high unemployment rate for vocational graduates. This is because the teacher in developing the module focuses more on hard skills than soft skills such as critical thinking skills and creativity skills. This study aims to analyze the content of the microcontroller lesson module on critical thinking skills and creativity of Vocational High School students. The research was conducted at the State Vocational High School 1 West Sumatra. The research used descriptive analysis method. This research focuses on the effect of module content on critical thinking skills and creativity of SMK students. The data collection technique used in this research is a questionnaire. Research subjects are teachers who teach microcontroller subjects. The data analysis technique used in this research is the mixed method. The results showed that the critical thinking skills and creativity of the students of SMK N 1 West Sumatra were in the very good category. In addition, the content of the lesson modules used to improve critical thinking skills and creativity of students of SMK N 1 West Sumatra.
\end{abstract}

Keywords: Vocational High School, Content, Modules, Critical Thinking, Creativity

Copyright (c) 2022 Teguh Wijaksana Isma, Elfi Tasrif, Yasdinul Huda, Nurhasan Syah $\triangle$ Corresponding author

Email : teguhwijaksana@gmail.com

DOI : https://doi.org/10.31004/edukatif.v4i1.1891

ISSN 2656-8063 (Media Cetak)

ISSN 2656-8071 (Media Online) 
583 Analisis Konten Modul Pelajaran Mikrokontroller Terhadap Keterampilan Berpikir Kritis dan Kreativitas Siswa Sekolah Menengah Kejuruan - Teguh Wijaksana Isma, Elfi Tasrif, Yasdinul Huda, Nurhasan Syah

DOI: https://doi.org/10.31004/edukatif.v4i1.1891

\section{PENDAHULUAN}

Pendidikan vokasional atau kejuruan adalah pendidikan yang bertujuan untuk menyiapkan sumber daya manusia yang berkualitas, siap kerja dan produktif di bidang tertentu. Pendidikan vokasi memberikan kepada peserta didik pengetahuan, keterampilan dan pengalaman untuk bekerja secara efisien dan produktif, serta kemampuan untuk selalu beradaptasi dan tetap terdepan dalam perkembangan ilmu pengetahuan dan teknologi. Pendidikan vokasional atau pendidikan kejuruan pada hakikatnya mengutamakan penyiapan lulusan menjadi tenaga kerja terampil. Dimana hakikat pendidikan vokasional harus cepat beradaptasi dengan perubahan. Keunggulan pendidikan vokasi ini adalah peserta didik dapat langsung mengembangkan keterampilannya sesuai dengan kebutuhan bidang atau bidang pekerjaan yang akan dihadapinya (Marfu'ah, 2016).

Salah satu permasalahan pada pendidikan vokasional saat ini adalah tingginya angka penggangguran lulusan pendidikan vokasional. Hal tersebut dapat dibuktikan dari grafik yang dapat dilihat dari gambar 1.1 Dari data yang terdapat pada gambar 1 dapat dilihat pengangguran lulusan pada lulusan vokasional setiap tahun terus meningkat. Hal ini menjadikan tujuan dari didirikannya Pendidikan Vokasional atau Kejuruan tampaknya kian menjauh dari jangkauan (Andini, 2021).

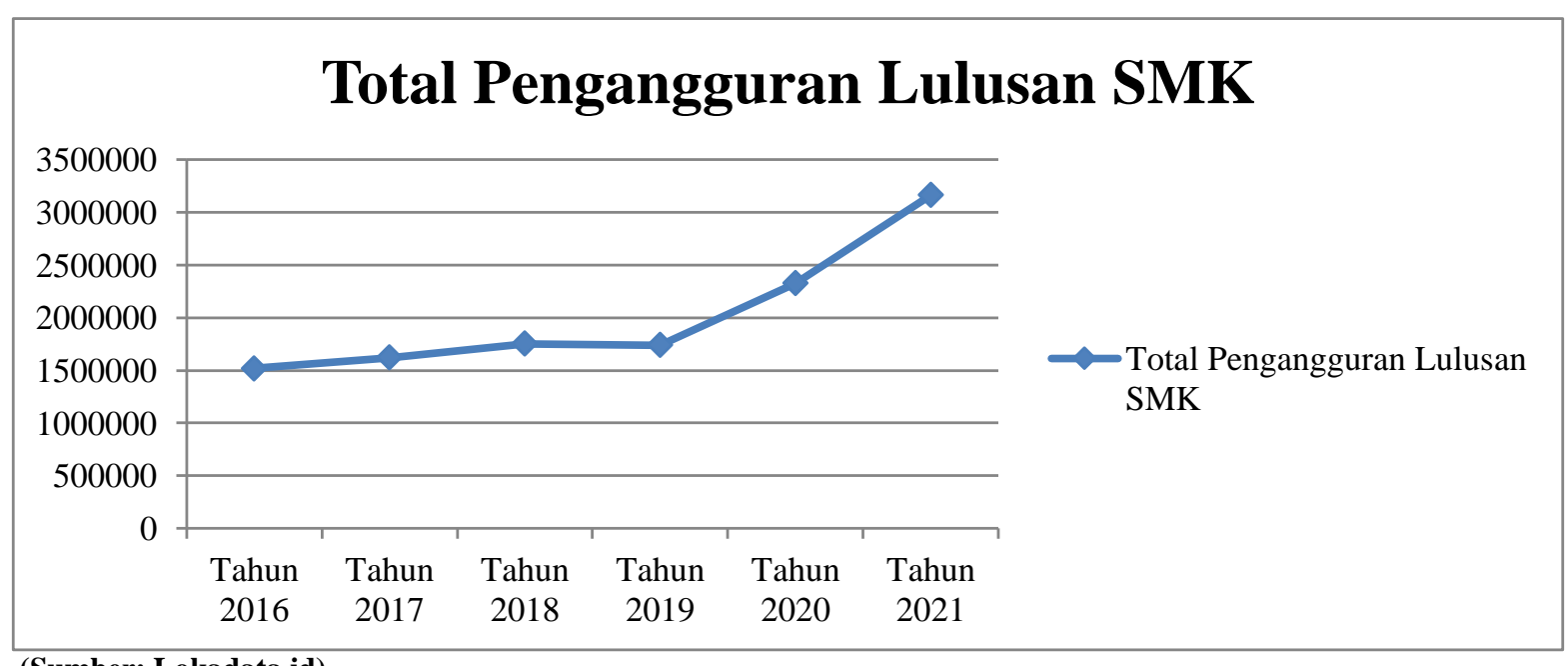

(Sumber: Lokadata.id)

Gambar 1. Total Pengangguran SMK dari Tahun 2016 - 2021

Data yang didapatkan dari tahun 2016 sampai 2021 yang terdapat pada gambar 1, dapat disimpulkan bahwa pengangguran yang terjadi pada lulusan pendidikan vokasional tiap tahunnya terus meningkat dengan puncaknya pada tahun 2021 yang mencapai lebih dari 3000000 siswa. Dengan tingginya pengangguran pada lulusan pendidikan vokasional menyebabkan tujuan dari pendidikan vokasional didirikan susah untuk dicapai.

Tingginya angka pengangguran pada pendidikan vokasional disebabkan oleh berbagai faktor seperti, ketersediaan daya serap lulusan vokasional di dunia industri atau dalam bidang usaha sedikit sehingga tidak mampu menampung seluruh lulusan vokasional. Faktor lainnya yang menyebabkan tingginya angka pengangguran adalah kompetensi yang dimiliki oleh lulusan vokasional lebih rendah dibandingkan dengan kompetensi yang dibutuhkan oleh dunia usaha atau dunia industri, bahkan kompetensi yang dilatih dan diajarkan oleh sekolah vokasional tidak sesuai dengan tuntutan pada dunia usaha dan dunia industri (Kemendikbud, 2015). 
584 Analisis Konten Modul Pelajaran Mikrokontroller Terhadap Keterampilan Berpikir Kritis dan Kreativitas Siswa Sekolah Menengah Kejuruan - Teguh Wijaksana Isma, Elfi Tasrif, Yasdinul Huda, Nurhasan Syah

DOI: https://doi.org/10.31004/edukatif.v4i1.1891

Selain itu Pengangguran lulusan SMK yang cukup besar disebabkan karena sistem pembelajaran SMK yang masih berpusat pada pengajaran hard skill, dan mengabaikan evaluasi yang berkaitan dengan soft skill sehingga menjadi salah satu penyebab rendahnya daya serap lulusan SMK di dunia kerja. Upaya pemerintah dalam mengatasi tingginya tingkat pengangguran lulusan SMK adalah dengan lahirnya kebijakan pemerintah tentang revitalisasi pendidikan SMK. Dari delapan standar pendidikan nasional salah satunya adalah berkaitan dengan standar penilaian pendidikan dalam hal ini terkait dengan evaluasi hasil proses belajar peserta didik, nampaknya belum banyak mendapat kajian yang komprehensif, terutama berkaitan dengan instrumen evaluasi yang diterapkan (Imansari, N., \& Sunaryatiningsih, 2017).

Kemampuan softskill yang harus dimiliki oleh lulusan SMK diantaranya adalah keterampilan berpikir kritis dan keterampilan kreativitas. Menurut pendapat dari Koes (2003) "Berpikir kritis dan berpikir kreatif merupakan keterampilan berpikir yang saling berkaitan dalam pandangan holistik tentang keterampilan berpikir manusia" (Supriyono Koes H, 2003). Sejalan dengan pendapat tersebut menurut Hassoubah (2002) "keterampilan berpikir kritis dan berpikir kreatif sangat penting untuk mengembangkan keterampilan lainnya yang dimiliki, seperti keterampilan untuk membuat keputusan dan penyelesaian permasalahan yang ada" (Hassoubah, 2004).

Keterampilan berpikir siswa yang semakin kritis dan kreatif akan menjamin ilmu pengetahuan yang diperoleh akan bertahan lebih lama sehingga akan berdampak pada hasil belajar siswa yang semakin meningkat. Hal tersebut sesuai dengan pendapat Caroselli (2009) yang menyatakan bahwa "kebiasaankebiasaan berpikir kritis dan berpikir kreatif siswa akan berefek potensial terhadap hasil belajar siswa di sekolah, dimana kebiasaan dari menyelesaikan masalah dengan kritis dan kreatif akan membiasakan siswa dalam menyelesaikan masalah secara tepat dan cepat" (Caroselli, 2009).

Salah satu upaya yang dapat dilakukan untuk mengatasi permasalahan pengangguran adalah mengembangkan modul pembelajaran dengan menggunakan konten yang tepat. Penggunaan konten yang tepat dalam modul dapat memudahkan dalam meningkatkan softskill. Hal ini didukung oleh penelitian yang dilakukan oleh Ervan Setya Bakti Nugroho yang menggunakan Relating, Experiencing, Applying, Cooperating Dan Transferring (REACT) sebagai konten dalam mengembangkan modul pembelajaran. Dari penelitian yang dilakukan tersebut penggunaan REACT sebagai konten dalam pengembangan modul pembelajaran dapat meningkatkan keterampilan berpikir kritis siswa.

Oleh karena itu, penelitian ini bertujuan untuk menganalisis konten modul pelajaran terhadap keterampilan berpikir kritis dan kreatif siswa SMK. Penelitian ini menjadi rekomendasi atau usulan bagi guru dalam memilih konten pembelajaran yang cocok untuk digunakan dalam pengembangan modul pembelajaran.

\section{METODE PENELITIAN}

Penelitian dilakukan dengan menggunakan metode deskriptif analisis. Penelitian ini bertujuan untuk menganalisis konten modul pelajaran mikrokontroller terhadap keterampilan berpikir kritis dan kreativitas siswa SMK di SMK N 1 Sumbar. Subjek penelitian adalah guru SMK yang mengajar mata pelajaran mikrokontroller sebanyak 3 orang. Pengumpulan data yang digunakan adalah angket. Angket yang diberikan kepada guru terdapat 20 butir pernyataan sedangkan angket yang diberikan kepada siswa terdapat 28 butir pernyataan. Instrumen penelitian ini dilakukan uji validitas dan realibilitas menggunakan software IBM SPSS Statistic 25 guna untuk menyempurnakan angket yang akan disebarkan. Adapun gradasi skala likert yang digunakan pada angket dapat dilihat pada tabel 1. 

Kreativitas Siswa Sekolah Menengah Kejuruan - Teguh Wijaksana Isma, Elfi Tasrif, Yasdinul Huda, Nurhasan Syah

DOI: https://doi.org/10.31004/edukatif.v4i1.1891

Tabel 1. Gradasi Skala Likert

\begin{tabular}{cc}
\hline Pernyataan & Skor Pernyataan \\
\hline 4 & Sangat Setuju \\
\hline 3 & Setuju \\
\hline 2 & Kurang Setuju \\
\hline 1 & Sangat Tidak Setuju \\
\hline
\end{tabular}

Teknik analisis data yang dilakukan adalah dengan metode mixed method. Analisis data kuantitatif dilakukan dengan beberapa tahapan sebagai berikut ini: (1) mentabulasi data angket yang sudah diisi oleh responden, (2) menghitung nilai dari setiap indikator, (3) menghitung nilai skor total, (4) melakukan analisis deskriptif dari data yang telah dikumpulkan. Sedangkan untuk analisis data kualitatif dilakukan dengan tahapan sebagai berikut: (1) Melakukan pengumpulan data, (2) melakukan reduksi data, (3) Melakukan penyajian data, dan (4) menarik kesimpulan.

\section{HASIL DAN PEMBAHASAN}

Hasil analisis yang diperoleh yang diberikan kepada guru SMK N 1 Sumbar yang mengajar sebanyak 3 orang dapat dilihat pada tabel 2.

Tabel 2. Hasil Analisis Data

\begin{tabular}{clcc}
\hline No & \multicolumn{1}{c}{ Indikator } & Index Nilai & Keterangan \\
\hline 1 & $\begin{array}{l}\text { Konten Modul Pelajaran Terhadap } \\
\text { Keterampilan Berpikir Kritis }\end{array}$ & 81.67 & Sangat Setuju \\
\hline 2 & $\begin{array}{l}\text { Konten Modul Pelajaran Terhadap } \\
\text { Keterampilan Kreativitas }\end{array}$ & 80 & Sangat Setuju \\
\hline
\end{tabular}

- Konten Modul Terhadap Keterampilan Berpikir Kritis

Keterampilan berpikir kritis adalah kemampuan siswa dalam menganalisis argumen, membuat kesimpulan menggunakan penalaran, menilai atau mengevaluasi, dan membuat keputusan atau pemecahan masalah (Lai, 2011). Keterampilan berpikir kritis seharusnya diberbedayakan melalui pembelajaran di sekolah khususnya pembelajaran sains, karena keterampilan berpikir kritis merupakan keterampilan berpikir abad 21 yang harus dimiliki Siswa (Anna Rosefsky Saavedra, \& Opfer, 2012). Berdasarkan hasil analisis data yang terdapat pada tabel 2 yang diberikan kepada guru SMK terkait konten modul terhadap keterampilan berpikir kritis siswa bahwa nilai index adalah $81.67 \%$ atau berada dalam kategori SANGAT SETUJU.

Adapun penerapan model pembelajaran dalam modul pembelajaran dalam upaya meningkatkan keterampilan berpikir kritis siswa dapat dilihat pada tabel 3 .

Tabel 3 Penerapan Model Pembelajaran dalam Peningkatan Keterampilan Berpikir Kritis Peserta Didik

\begin{tabular}{clccc}
\hline No & \multicolumn{1}{c}{ Judul Penelitian } & $\begin{array}{c}\text { Model } \\
\text { Pembelajaran }\end{array}$ & Tahun & $\begin{array}{c}\text { Peningkatan } \\
\text { Keterampilan } \\
\text { Kolaborasi }\end{array}$ \\
\hline & $\begin{array}{l}\text { Pengembangan modul bioteknologi berbasis } \\
\text { Problem Based Learning (PBL) untuk } \\
\text { meningkatkan hasil belajar, kemampuan berpikir } \\
\text { kritis dan sikap siswa kelas XII SMKN 2 Batu }\end{array}$ & $\begin{array}{c}\text { Problem Based } \\
\text { Learning }\end{array}$ & 2021 & $\begin{array}{c}\text { Terjadi } \\
\text { Peningkatan }\end{array}$ \\
\hline 2 & Pengembangan Modul Pembelajaran Fisika & Keterampilan & 2017 & Terjadi \\
\hline
\end{tabular}


586 Analisis Konten Modul Pelajaran Mikrokontroller Terhadap Keterampilan Berpikir Kritis dan Kreativitas Siswa Sekolah Menengah Kejuruan - Teguh Wijaksana Isma, Elfi Tasrif, Yasdinul Huda, Nurhasan Syah

DOI: https://doi.org/10.31004/edukatif.v4i1.1891

\begin{tabular}{|c|c|c|c|c|}
\hline No & Judul Penelitian & $\begin{array}{c}\text { Model } \\
\text { Pembelajaran }\end{array}$ & Tahun & $\begin{array}{c}\text { Peningkatan } \\
\text { Keterampilan } \\
\text { Kolaborasi } \\
\end{array}$ \\
\hline & $\begin{array}{l}\text { Berbasis Keterampilan Proses Sains (KPS) Dalam } \\
\text { Meningkatkan Berfikir Kritis Siswa Smk Kelas XI }\end{array}$ & $\begin{array}{l}\text { Proses Sains } \\
\text { (KPS) }\end{array}$ & & Peningkatan \\
\hline 3 & $\begin{array}{l}\text { Pengembangan Modul Fisika Berbasis Interactive } \\
\text { Demonstration Untuk Meningkatkan Keterampilan } \\
\text { Berpikir Kritis Dan Penguasaan Konsep Siswa } \\
\text { SMA/MA Pada Materi Mekanika Fluida }\end{array}$ & $\begin{array}{l}\text { Interactive } \\
\text { Demonstration }\end{array}$ & 2018 & $\begin{array}{c}\text { Terjadi } \\
\text { Peningkatan }\end{array}$ \\
\hline 4 & $\begin{array}{l}\text { Pengembangan Modul Fisika Berbasis OASIS } \\
\text { Pada Materi Suhu dan Kalor Untuk Meningkatkan } \\
\text { Kemampuan Berpikir Kritis }\end{array}$ & OASIS & 2020 & $\begin{array}{c}\text { Terjadi } \\
\text { Peningkatan }\end{array}$ \\
\hline 5 & $\begin{array}{l}\text { Pengembangan Modul Suhu dan Kalor Berbasis } \\
\text { Project Based Learning untuk Meningkatkan } \\
\text { Keterampilan Proses Sains dan Kemampuan } \\
\text { Berpikir Kritis Siswa SMA/MA } \\
\end{array}$ & $\begin{array}{l}\text { Project Based } \\
\text { Learning }\end{array}$ & 2018 & $\begin{array}{c}\text { Terjadi } \\
\text { Peningkatan }\end{array}$ \\
\hline 6 & $\begin{array}{l}\text { Pengembangan Modul Pembelajaran Tentang } \\
\text { Perubahan Lingkungan Berbasis Konstruktivisme } \\
\text { Untuk Meningkatkan Keterampilan Berpikir Kritis } \\
\text { Dan Kreatif }\end{array}$ & Konstruktivisme & 2020 & $\begin{array}{c}\text { Terjadi } \\
\text { Peningkatan }\end{array}$ \\
\hline 7 & $\begin{array}{l}\text { Pengembangan Modul Pembelajaran Berbasis } \\
\text { Online Moodlecloud Berbantu Cisco Packet Tracer } \\
\text { Untuk Meningkatkan Critical Thinking Siswa } \\
\text { Kelas XI Mata Pelajaran Teknologi Layanan } \\
\text { Jaringan }\end{array}$ & $\begin{array}{l}\text { Online } \\
\text { Moodlecloud } \\
\text { Berbantu Cisco } \\
\text { Packet Tracer }\end{array}$ & 2020 & $\begin{array}{c}\text { Terjadi } \\
\text { Peningkatan }\end{array}$ \\
\hline 8 & $\begin{array}{l}\text { Pengembangan Modul Berbasis Discovery } \\
\text { Learning Untuk Meningkatkan Kemampuan } \\
\text { Berpikir Kritis Dan Hasil Belajar Siswa }\end{array}$ & $\begin{array}{l}\text { Discovery } \\
\text { Learning }\end{array}$ & 2019 & $\begin{array}{c}\text { Terjadi } \\
\text { Peningkatan }\end{array}$ \\
\hline
\end{tabular}

Berdasarkan tabel 3 dapat dilihat bahwa model pembelajaran yang dapat digunakan untuk meningkatkan keterampilan berpikir kritis adalah menggunakan model pembelajaran Problem Based Learning, Keterampilan Proses Sains (KPS), Interactive Demonstration, OASIS, Project Based Learning, Konstruktivisme, Online Moodlecloud Berbantu Cisco Packet Tracer, dan Discovery Learning.

Hasil penelitian ini sesuai dengan penelitian yang dilakukan oleh Ervan Setya Bakti Nugroho pada tahun 2018 yang berjudul Pengembangan Modul berbasis Relating, Experiencing, Applying, Cooperating Dan Transferring (REACT) Pada materi Jamur Untuk Meningkatkan Kemampuan Berpikir Kritis Siswa Kelas X SMK. Hasil penelitian tersebut adalah bahwa pengembangan modul pembelajaran berbasis Relating, Experiencing, Applying, Cooperating Dan Transferring (REACT) dapat meningkatkan keterampilan kolaborasi siswa sebanyak $16.16 \%$.

- Konten Modul Terhadap Keterampilan Kreativitas

Keterampilan berpikir kreatif (creative thinking) yaitu keterampilan individu dalam menggunakan proses berpikirnya untuk menghasilkan gagasan yang baru, konstruktif berdasarkan konsep-konsep dan prinsip-prinsip yang rasional maupun persepsi, dan intuisi individu (Ahmadi, I.K, 2011). Berdasarkan hasil penelitian yang diberikan kepada guru SMK terkait konten modul terhadap keterampilan kreativitas siswa bahwa nilai index adalah $81.67 \%$ atau berada dalam kategori SANGAT SETUJU.

Adapun penerapan model pembelajaran dalam modul pembelajaran dalam upaya meningkatkan keterampilan kreativitas dapat dilihat pada tabel 4 . 
587 Analisis Konten Modul Pelajaran Mikrokontroller Terhadap Keterampilan Berpikir Kritis dan Kreativitas Siswa Sekolah Menengah Kejuruan - Teguh Wijaksana Isma, Elfi Tasrif, Yasdinul Huda, Nurhasan Syah

DOI: https://doi.org/10.31004/edukatif.v4i1.1891

Tabel 4. Penerapan Model Pembelajaran dalam Peningkatan Keterampilan Kreativitas Peserta Didik

\begin{tabular}{|c|c|c|c|c|}
\hline No & Judul Penelitian & $\begin{array}{c}\text { Model } \\
\text { Pembelajaran }\end{array}$ & Tahun & $\begin{array}{c}\text { Peningkatan } \\
\text { Keterampilan } \\
\text { Kolaborasi } \\
\end{array}$ \\
\hline 1 & $\begin{array}{l}\text { Efektivitas E-Modul Project Based Learning } \\
\text { Berintegrasi STEM Terhadap } \\
\text { Kreativitas Siswa SMK }\end{array}$ & $\begin{array}{l}\text { Project Based } \\
\text { Learning } \\
\text { Berintegrasi } \\
\text { STEM } \\
\end{array}$ & 2020 & $\begin{array}{c}\text { Terjadi } \\
\text { Peningkatan }\end{array}$ \\
\hline 2 & $\begin{array}{l}\text { Pengaruh Penerapan Modul Fisika Berbasis OASIS } \\
\text { Untuk Meningkatkan Kreativitas Siswa }\end{array}$ & OASIS & 2020 & $\begin{array}{c}\text { Terjadi } \\
\text { Peningkatan }\end{array}$ \\
\hline 3 & $\begin{array}{l}\text { Modul Daring Berbasis Creative Problem Solving } \\
\text { untuk Meningkatkan Kemampuan Berpikir Kreatif }\end{array}$ & $\begin{array}{l}\text { Creative } \\
\text { Problem } \\
\text { Solving }\end{array}$ & 2019 & $\begin{array}{c}\text { Terjadi } \\
\text { Peningkatan }\end{array}$ \\
\hline 4 & $\begin{array}{l}\text { Pengembangan Modul Fisika Berbasis Masalah } \\
\text { Pada Materi Listrik Dinamis Untuk Meningkatkan } \\
\text { Kemampuan Berpikir Kreatif } \\
\text { Siswa SMA }\end{array}$ & $\begin{array}{l}\text { Problem Based } \\
\text { Learning }\end{array}$ & 2014 & $\begin{array}{c}\text { Terjadi } \\
\text { Peningkatan }\end{array}$ \\
\hline 5 & $\begin{array}{l}\text { Pengembangan Modul Digital Pembelajaran } \\
\text { Matematika Berbasis Pendekatan Open Ended } \\
\text { Untuk Meningkatkan Kemampuan Berpikir Kreatif } \\
\text { Matematis }\end{array}$ & Open Ended & 2020 & $\begin{array}{c}\text { Terjadi } \\
\text { Peningkatan }\end{array}$ \\
\hline 6 & $\begin{array}{l}\text { Pengaruh Penerapan Modul Fisika Berbasis Oasis } \\
\text { Untuk Meningkatkan Kreativitas Siswa }\end{array}$ & OASIS & 2020 & $\begin{array}{c}\text { Terjadi } \\
\text { Peningkatan }\end{array}$ \\
\hline 7 & $\begin{array}{l}\text { Pengaruh model pembelajaran creative problem } \\
\text { solving terhadap kemampuan berpikir kreatif siswa } \\
\text { pada materi program linier kelas XI SMK }\end{array}$ & $\begin{array}{l}\text { Creative } \\
\text { Problem } \\
\text { Solving }\end{array}$ & 2017 & $\begin{array}{c}\text { Terjadi } \\
\text { Peningkatan }\end{array}$ \\
\hline 8 & $\begin{array}{l}\text { Pengembangan Modul Pembelajaran Matematika } \\
\text { Dengan Strategi PQ4R Untuk Meningkatkan } \\
\text { Kemampuan Berpikir Kreatif Dan Kemandirian } \\
\text { Belajar Siswa SMA }\end{array}$ & Strategi PQ4R & 2019 & $\begin{array}{c}\text { Terjadi } \\
\text { Peningkatan }\end{array}$ \\
\hline 9 & $\begin{array}{l}\text { Pengembangan Modul Fisika Berbasis Sets Dengan } \\
\text { Metode Eksperimen Untuk Meningkatkan } \\
\text { Kemampuan Berpikir Kreatif Siswa SMK Qomarul } \\
\text { Hidayah } 1 \text { Tugu Kelas XI Materi Termodinamika }\end{array}$ & $\begin{array}{l}\text { Sets Dengan } \\
\text { Metode } \\
\text { Eksperimen }\end{array}$ & & $\begin{array}{c}\text { Terjadi } \\
\text { Peningkatan }\end{array}$ \\
\hline 10 & $\begin{array}{l}\text { Pengembangan Modul Fisika STEM Terintegrasi } \\
\text { Kearifan Lokal "Beduk" untuk Meningkatkan } \\
\text { Kemampuan Berpikir Kreatif Siswa SMP }\end{array}$ & $\begin{array}{c}\text { STEM } \\
\text { Terintegrasi } \\
\text { Kearifan Lokal }\end{array}$ & 2019 & $\begin{array}{c}\text { Terjadi } \\
\text { Peningkatan }\end{array}$ \\
\hline
\end{tabular}

Berdasarkan tabel 4 dapat dilihat bahwa model pembelajaran yang dapat digunakan untuk meningkatkan keterampilan kreativitas adalah menggunakan model pembelajaran Project Based Learning Berintegrasi STEM, OASIS, Creative Problem Solving, Problem Based Learning, Open Ended, Strategi PQ4R, Sets Dengan Metode Eksperimen, dan STEM Terintegrasi Kearifan Lokal.

Hasil penelitian ini sesuai dengan penelitian yang dilakukan oleh Udi Nugroho pada tahun 2018 yang berjudul Pengembangan Modul Elastisitas Berbasis Inkuiri Terbimbing Untuk Mengembangkan Disiplin Belajar Dan Kreativitas Siswa SMK. Hasil penelitian tersebut adalah bahwa pengembangan modul pembelajaran berbasis inkuiri terbimbing efektif untuk meningkatkan kreativitas siswa dengan kategori sedang berdasarkan hasil $\mathrm{N}$-gain score 0,51 . 
588 Analisis Konten Modul Pelajaran Mikrokontroller Terhadap Keterampilan Berpikir Kritis dan Kreativitas Siswa Sekolah Menengah Kejuruan - Teguh Wijaksana Isma, Elfi Tasrif, Yasdinul Huda, Nurhasan Syah

DOI: https://doi.org/10.31004/edukatif.v4i1.1891

\section{KESIMPULAN}

Berdasarkan penelitian yang telah dilakukan kepada guru SMK terkait konten modul terhadap keterampilan berpikir kritis siswa bahwa nilai index adalah $81.67 \%$ atau berada dalam kategori SANGAT SETUJU. Sedangkan terkait konten modul terhadap keterampilan kreativitas siswa bahwa nilai index adalah $81.67 \%$ atau berada dalam kategori SANGAT SETUJU. Model pembelajaran yang dapat digunakan sebagai konten dalam modul pembelajaran untuk meningkatkan keterampilan berpikir kritis adalah menggunakan model pembelajaran Problem Based Learning, Keterampilan Proses Sains (KPS), Interactive Demonstration, OASIS, Project Based Learning, Konstruktivisme, Online Moodlecloud Berbantu Cisco Packet Tracer, dan Discovery Learning. Sedangkan model pembelajaran yang dapat digunakan sebagai konten pembelajaran untuk meningkatkan keterampilan kreativitas adalah menggunakan model pembelajaran Project Based Learning Berintegrasi STEM, OASIS, Creative Problem Solving, Problem Based Learning, Open Ended ,Strategi PQ4R, Sets Dengan Metode Eksperimen, dan STEM Terintegrasi Kearifan Lokal. Dengan penelitian yang dilakukan dapat dijadikan sebagai rekomendasi bagi guru dan mahasiswa dalam mengembangkan modul pelajaran kedepannya. Selain itu dalam pengembangan modul pelajaran kedepannya guru atau mahasiswa tidak hanya memfokuskan pengembangan dalam masalah hardskill siswa namun juga softskill siswa seperti keterampilan berpikir kritis dan kreativitas.

\section{DAFTAR PUSTAKA}

Ahmadi, I.K, Dkk. (2011). Strategi Pembelajaran Sekolah Terpadu. Prestasi Pustaka.

Andini, A. (2021). Pengangguran Kian Besar, Pemerintah Harus Merevolusi Smk. Lokadata. Https://Lokadata.Id/Artikel/Pengangguran-Kian-Besar-Pemerintah-Harus-Merevolusi-Smk

Anna Rosefsky Saavedra, \& Opfer, V. D. (2012). Learning 21st-Century Skills Requires 21st-Century Teaching. Phi Delta Kappan, 8-13. Https://Doi.Org/Https://Doi.Org/10.1177/003172171209400203

Auliah, L., Syaiful, S., \& Syamsurizal, S. (2020). Pengembangan Modul Digital Pembelajaran Matematika Berbasis Pendekatan Open Ended Untuk Meningkatkan Kemampuan Berpikir Kreatif Matematis. Jurnal Pendidikan Matematika, 11(1), 13. Https://Doi.Org/10.36709/Jpm.V11i1.9885

Cahyani, A. E. M., Mayasari, T., \& Sasono, M. (2020). Efektivitas E-Modul Project Based Learning Berintegrasi Stem Terhadap Kreativitas Siswa Smk. Jurnal Ilmiah Pendidikan Fisika, 4(1), 15. Https://Doi.Org/10.20527/Jipf.V4i1.1774

Caroselli, M. (2009). 50 Activities For Developing Critical Thinking Skills. Hrd Press.

Hasanah, I., Sarwanto, S., \& Masykuri, M. (2018). Pengembangan Modul Suhu Dan Kalor Berbasis Project Based Learning Untuk Meningkatkan Keterampilan Proses Sains Dan Kemampuan Berpikir Kritis Siswa Sma/Ma. Jurnal Pendidikan (Teori Dan Praktik), 3(1), 38. Https://Doi.Org/10.26740/Jp.V3n1.P38-44

Hassoubah, I. J. (2004). Cara Berpikir Kreatif Dan Kritis. Nuansa.

Imansari, N., \& Sunaryatiningsih, I. (2017). Pengaruh Penggunaan E-Modul Interaktif Terhadap Hasil Belajar Mahasiswa Pada Materi Kesehatan Dan Keselamatan Kerja. Jurnal Ilmiah Pendidikan Teknik Elektro, $11-16$.

Kemendikbud. (2015). Grand Design Pengembangan Teaching Factory Dan Technopark Di Smk. Dit. Psmk Kemendikbud. 
589 Analisis Konten Modul Pelajaran Mikrokontroller Terhadap Keterampilan Berpikir Kritis dan Kreativitas Siswa Sekolah Menengah Kejuruan - Teguh Wijaksana Isma, Elfi Tasrif, Yasdinul Huda, Nurhasan Syah

DOI: https://doi.org/10.31004/edukatif.v4i1.1891

Lai, E. R. (2011). Critical Thinking: A Literatur Review. Pearson. Http://Www.Pearsonassessments.Com.

Marfu'ah, S. (2016). Pendidikan Kejuruan. Https://Pdfcoffee.Com/Pendidikan-Kejuruan-Pdf-Free.Html

Marrysca, A. F. V. (2016). Pengembangan Modul Pembelajaran Fisika Berbasis Ketrampilan Proses Sains (Kps) Dalam Meningkatkan Berfikir Kritis Siswa Smk Kelas Xi.

Noviyanti, \& Hardini, A. T. A. (2021). Pengembangan Modul Bahasa Indonesia Materi Puisi Menggunakan Model Mind Mapping Di Sekolah Dasar. 3(5), 3277-3286. Https://Edukatif.Org/Index.Php/Edukatif/Article/View/1271/Pdf

Prihantoro Eko Sulistyo, Suparmi Suparmi, S. S. (2018). Pengembangan Modul Fisika Berbasis Interactive Demonstration Untuk Meningkatkan Keterampilan Berpikir Kritis Dan Penguasaan Konsep Siswa Sma/Ma Pada Materi Mekanika Fluida. Jurnal Inkuiri.

Rolia, Rosmaiyadi, N. H. (2017). Pengaruh Model Pembelajaran Creative Problem Solving Terhadap Kemampuan Berpikir Kreatif Siswa Pada Materi Program Linier Kelas Xi Smk Rolia,. V O X E D U K A $S I, 8(2)$.

Sudaryati, A. (2017). Listrik Dinamis Untuk Meningkatkan Kemampuan Berpikir. 6(3).

Sukaryawan, M., Sari, D. K., Unsri, P. K., \& Pendahuluan, I. (2016). Pelatihan Dan Pembimbingan Pembuatan Modul Bagi Guru Kimia Sma Di Lubuklinggau, Musirawas.

Supriyono Koes H. (2003). Strategi Pembelajaran Fisika. Universitas Negeri Malang.

Undang-Undang Guru Dan Dosen No. 14 Tahun 2015. 